\title{
The Pressure on Women Teachers in Colleges and Countermeasures
}

\author{
Dongyu Zhao ${ }^{1}$ \\ ${ }^{1}$ Qingdao University of Science and Technology, Qingdao, Shangdong, China \\ Correspondence: Dongyu Zhao, Qingdao University of Science and Technology, No.99 Songling Road, Qingdao \\ City, 266061, China. Tel: 86-532-8895-8268. E-mail: zdyhao@126.com
}

Received: December 25, 2014 Accepted: January 9, 2015 Online Published: March 16, 2015

doi:10.5539/ass.v11n7p35

URL: http://dx.doi.org/10.5539/ass.v11n7p35

\begin{abstract}
Women teachers in colleges is a group with higher cultural level, however, they are under pressure from many aspects such as from family, society, work, self-development and so on, which have formed a potential threat on their physical and mental health. School party and government leaders and women's organizations should pay full attention to women teachers, and provide help and support for them as much as possible to ensure they can get better development. Furthermore, women teachers must handle the conflicts between work, family, learning and self-development correctly, and then find a balance between busy work and heavy housework. Meanwhile, for the sake of taking effective measures to alleviate pressure, it is particularly important for women teachers to build esteem, self-confidence, self-reliance, enhance business learning and improve personal qualities and ability.
\end{abstract}

Keywords: women teachers in colleges, pressure, countermeasure

\section{Preface}

Women teachers in colleges are a group with higher cultural level. The majority of women teachers who play a significant role in China's modernization and social progress are the one can esteem, self-confidence, self-reliance, self-reliance, which manifest as the correct world outlook, values, outlook on life, financially independent, and ideological emancipation. However, it is undeniable that the conflict among special role of women, the existence of contradictions in reality and the knowledge economy under traditional concept cause some college women teachers in this group more or less confront with the pressure stem from the family, social and work and so on. How to effectively mitigate the pressures faced by college women teachers and ensure the better development of the majority of women teacher is worthy of serious study and discussion.

\section{Complete Analysis about Pressures}

\subsection{Pressures from Family}

First, many of the young women teachers in colleges are faced with the pressure on choosing a spouse. Many of them has no mind and no time to consider the individual's marriage problem due to the task of completing their studies in master's or doctoral school age, unfortunately, they have reached the age to get married until the time the graduate, many of which have nearly thirty years of age. In the meantime, they have higher requirements in selecting future partner because of their older age and high level of education and knowledge. The reason that many older women teachers are faced with pressure of choosing mates stems from two aspects, On one hand, the chances for women teachers to experience actual peer relations is relatively small due to the limitations of the work, on the other hand, women teachers of high-level in the community have relatively few opportunities contacts with men due to this particular university environment which is relatively less open in interpersonal relationships compared to society.

Apart from the above pressures, the married women teachers are faced with having children, maternity, child and elder care, and many other domestic problems. With the accelerating pace of modern life and continuous reform of university personnel system, college women teachers are faced with conflict between heavy housework and busy work, the stress come from family and work both.

\subsection{Pressures from Work}

Women teachers in colleges must add new knowledge to optimize their knowledge structure and enhance their teaching ability continuously which is attributed to the curriculum reform and constant update of knowledge. 
Owing to the purpose of improving the standard of teaching, women teachers dare to explore unceasingly to overcome the practical teaching pressures. In intellectual work whoever want to associate with professional title must publish many quality articles on influential publications in accordance with specified criteria and complete the required task of teaching and research work in time, which are hard for women teachers. Many women teachers do incredible work to get professional title, only to find come to nothing. It is the ambitions of women teachers to have greater development that virtually increased the pressure, which are on account of the more obstacles; accompany with women teachers, as well as the far more effort needed to finish their job.

\subsection{Pressures from Scientific Research}

Because of the universal importance of teaching and research in university work, many universities regard work as a rigid scientific assessment indicator, which undoubtedly aggravate the pressure of college research on women teachers. It is difficult for many women teachers to apply for research independently due to many factors; even those who can apply for the research can not find a way to complete the research tasks perfectly. So they often spend a lot of effort on the tasks, sometimes even cost several years to finish it.

\subsection{Pressures from Self-development}

Women teachers need to improve academic standards and perfect knowledge structure constantly so as to adapt to the rapidly changing era of knowledge economy, which requires them to challenge themselves continuously, study unceasingly and enterprising. Many women teachers improve personal quality and level by raising education levels or joining in-service education, training and other ways. Nowadays, $\mathrm{PhD}$ has become a popular choice of women teachers to improve education. However, the energy, finance and effort paid to $\mathrm{PhD}$ make women teachers overburdened. Some women teachers in colleges own less development opportunities than male teachers. Women teachers are facing "glass ceiling" in the workplace which refers to certain obstacles invisible to human development and is actually exist.

\section{Countermeasures and Suggestions about How to Reduce Stress}

Women teachers in colleges are overwhelmed by the pressures that derive from the presence of family, work, self-development and many other aspects, which affects not only their physical health and mental health, but also may give psychological crisis seriously. Therefore, the colleges should imperatively take measures to alleviate the pressure in order to guarantee physical and mental health of women university teachers.

\subsection{Suggestion for the School Party Leaders to Give Full Attention to the Pressure}

For the sake of creating an environment which is suitable for the development of women teachers, school party and government leaders consider the interests of women teachers roundly, listen to their voices and care about the requirements of their work and development at the time organizing and formulating relevant policies. Meanwhile, Women's organizations in colleges should take measures to reduce the pressures on women teachers. Recently, the activity of Women's committee and organizations in colleges has exerted dramatic influence on the pressure of women teachers, they should understand and care women teachers and protect the rights and interests of women teachers actively. In order to alleviate pressure on many women teachers, they can participate in salon, women lectures, single teacher's parties and other recreational activities regularly held by women's organizations. Women teachers are given help and support in terms of learning funds, work arrangements, which are available to make them develop better.

\subsection{Women Teachers in Colleges Must Develop the Spirit of Self-Esteem, Self-Confidence, Self-Reliance to Improve Their Competitiveness}

Women teachers in colleges need to continuously improve quality of them and strengthen business learning. We believe that Women teachers can mitigate development pressure and working pressure by improving personal qualities and ability continually.

\subsection{Women Teachers in Colleges Should Handle the Contradiction between Work and Family Correctly}

Women teachers need to find a balance point between busy work and heavy housework, which is inevitable that women teachers should carry forward the spirit of ensuring hardship and master more ability to take care of family. Since it is impossible for women teachers to do everything perfectly in multiple roles, how to concentrate more time and energy into the activities they desired according to the urgency of the case divide priorities stand out.

\subsection{Women Teachers in Colleges Should Develop a Variety of Hobbies in Free Time to Relax Body and Mind}

Due to the physical and mental exhaustion caused by the too much pressure in the work life, women teachers should focus on relaxing in an effective way after the busy work. We give advice on women teachers to develop 
some life-loving hobbies in their spare time. Broad hobbies such as drawing, handwriting, bodybuilding, photography and participating in club activities will cultivate character, purify the mind and relieve the pressure comes from reality. In addition, cleansing the soul by closing to nature and doing more outdoor sports is also a good way for women teachers to relieve stress.

\section{Conclusions}

Women teachers in colleges are faced with pressures from family, work, scientific research, self-development, and many other aspects. Schools, women's organizations and women teachers themselves should attach great importance to behavior positively and take various measures and ways to relieve the pressure on women teachers effectively, especially unite and mobilize them together to realize their own progress and development while promote social and economic advance.

\section{Acknowledgements}

The author would like to acknowledge the support by the 2014 Qingdao University of Science and Technology human and social science program (No.13XB28,) and the 2014 Qingdao Social Science Planning Project (No.QDSKL1401061).

\section{References}

Feng, H. (2011). The Psychological Pressure Explanation and Countermeasure for the Youth Female Faculty in Colleges and Universities (Master's thesis, Wuhan University of Technology, Wuhan, China). Retrieved from http://d.wanfangdata.com.cn/Thesis_Y1880783.aspx

Guo, L., \& Zhang, L. (2010). Research on the psychological pressure and coping style of female teachers in Colleges and Universities. Journal of China Women's University, 2, 24-28. Retrieved from http://www.cqvip.com/QK/90477X/201002/33805280.html

Yang, Y. (2013). Pressure on Female Teachers in Colleges and Universities and Countermeasure. Journal of Chongqing University of Education, 26(2), 110-113. Retrieved from http://oldweb.cqvip.com/qk/82566A/ 201302/45261442.html

\section{Copyrights}

Copyright for this article is retained by the author(s), with first publication rights granted to the journal.

This is an open-access article distributed under the terms and conditions of the Creative Commons Attribution license (http://creativecommons.org/licenses/by/3.0/). 